\title{
LESSONS FROM THE BAN OF TWITTER IN NIGERIA: A TALE OF TWO WRONGS AND A "LOSE-LOSE" SITUATION
}

\author{
Philip Teniola David \\ Department of Mass Communication, Dominion University Ibadan
}

Article DOI: $\underline{\text { https://doi.org/10.36713/epra8490 }}$

DOI No: 10.36713/epra8490

\begin{abstract}
Freedom of expression suffered a major setback in Nigeria when the federal government placed an indefinite suspension on twitter in the country, much to the displeasure and criticism of many from within and without. Even though Nigerians found an alternative means of accessing the social media application through the use of virtual private networks ( $V P N$ ), the rippling effect of the ban from the social, political and economic viewpoint leaves much to be desired. After a prolonged tussle between the Nigerian government and the American based company which lasted over 100 days, the government finally agreed to have the ban lifted. This study through the use of secondary data investigates the emerging and contending issues surrounding the suspension. Findings reveal that the entire fiasco was quite avoidable had either of the parties not attempt to test waters.
\end{abstract}

\section{INTRODUCTION}

There is an overwhelming degree of literature that reinforces the relevance of information freedom in any democracy, and that includes Nigeria. Article 19 of the Universal Declaration of Human Rights and Article 19 of the International Covenant on Civil and Political Rights both state that everyone has the right to freedom of speech and the right to seek and transmit information. However, recent developments within the course of the year particularly the federal government ban on twitter in the country have raised serious questions on the practicability of this right in Nigeria. The government suspended twitter over a tweet they termed offensive, even though this was later denied with claims that the social media application was banned due to security reasons. Either ways, the move received wide criticisms both from within and outside Nigeria. It is widely believed that the ban has negatively affected several aspects of the country's social, economic and political sphere. That being said, certain school of thought both from within and outside the country have also questioned the sentiments of the American based outfit in meddling in the internal political affairs of the country. The argument is further substantiated on the fact that Twitter which is very trigger happy over an arbitrary set of rules to deny people the right to speak out is trying to be the champion of free speech. This has become a subject of debate as to what exactly does twitter defines as offensive. According to a Liberal studies scholar Micheal Rectenwald, "twitter has no business deciding on what geopolitical figures have to say about anything because they do not have sufficient facts to do so, they are just responding based on their own political prejudices with very limited knowledge about what the entire situation, they are simply just trying to instigate their own government or power. Similarly, Russia's director of information Maria Zakharova argues that the "information monster" even if it appears very 


\title{
EPRA International Journal of Research and Development (IJRD)
}

\author{
Volume: 6 | Issue: 9 | September $2021 \quad$ - Peer Reviewed Journal
}

attractive cannot dictate to a foreign state how to live, how to interpret historical events, what movies to watch or what music to listen to. Otherwise, instead of freedom of speech, it becomes a dictatorship of opinion for sole purpose. Adaobi cited in BBC News (2021), also posits that even though the company is entitled to enforce its rules, the message of Mr. Buhari was a formal statement from the President of Nigeria to his people tweeted via a state account. The identical message was also aired throughout the nation on various media outlets. Is it correct that an American private company has the authority without authorisation to alter the official message of a democratically elected president of an African country? It's no neo-colonial more than that. She argues that Nigerians have a right to know the goals and tactics of their leaders, regardless of their choice of words or their intentions. Against the backdrop of this argument, this study examines the antecedents of the twitter ban in Nigeria as well as it effect from the political, social and economic point of view.

\section{CONCEPT OF PRESS FREEDOM}

Omoera (2011), argues that press freedom is a subject of intense discussion across all continents because of how essential it is to a country's sociopolitical and economic growth. He cites the example of the United States, which has a significant role in the development of its media. The right of the press to "publish without fear of intimidation, threat, molestation, or blackmail," according to Onagoruwa (1985), is defined as the freedom to "publish without fear of intimidation, threat, molestation, or blackmail." Press freedom, according to Alabi (2003), refers to the capacity of journalists to disseminate their work without being subjected to prior restrictions. According to its most basic definition, press freedom refers to the fact that news media are not subject to censorship by the government, either directly or via intermediaries. Consequently, attempts to limit or prohibit particular information from being released by the press are not authorised by the federal government. While this may seem to be beneficial, media organisations would be confronted with the problem of suddenly "applying brakes" to their own choices about which material to disclose to the broader public, which would be difficult (Maduabuchi, 2011). Press freedom is a critical component of democratic culture, and the higher the quantity of press freedom in a country, the greater the freedom of democracy in that country. There is a growing understanding that the right to seek information encompasses the right to freedom of expression and expression. According to Harcup
(2014), freedom of speech is considered to be a crucial component of, and in some instances a prerequisite for, the freedom of the press. Momoh (2002), affirms that press freedom is an essential component of democracy; rules regulating the press in democratic nations are those that aim solely to safeguard the basic rights of people while also ensuring the maintenance of peace and order. Nigeria currently occupies the $120^{\text {th }}$ position in the World Press Freedom Index compiled by Reporters Without Borders (2021).

\section{SOCIAL MEDIA}

According to Akase et.al, (2020), websites that enable users to maintain social ties by viewing, visiting, and sharing their lists of social connections with other members are known as social media sites (also known as social networking sites). Online discussion forums and chat rooms; community-based personal websites and other social spaces available to users for the exchange of personal contact and communication are examples of this kind of social space. Facebook, Twitter, LinkedIn, YouTube, Instagram, and MySpace are just a few examples of social media platforms. Social networking websites provide a diverse range of tools and services, including texting, talking, blogging, uploading, and sharing movies and pictures, among other things. It is not only the function of social media sites to facilitate effective communication, but it is also the development of collaboration and networking among users. Undergraduates can meet new people and broaden their social circle by connecting with and interacting with their peers on social networking sites (Talabi, 2011). These connections can be useful for a variety of things, including: finding love, looking for a new job, locating assistance, receiving and giving product and service referrals, receiving support from like-minded individuals, and giving or receiving advice on career or personal issues, among other things. Another advantage of utilising social media is that it provides access to entertainment (music and video), and Facebook has recently gained popularity as a result of new gaming apps that have emerged in the past couple of years. One of the advantages of using social media is the ability to share information in real time. Rodman (2020), for example argues that many social media platforms include an instant messaging feature, which allows users to exchange information in real time through a chat. Social media platforms have been proven to be very helpful in sharing or distributing information such as breaking news, research results, and the newest worldwide trend on a variety of problems, including catastrophe outbreaks. Edogor et. al, (2014), submits that the fundamental processes 


\section{EPRA International Journal of Research and Development (IJRD)}

involved in news gathering and dissemination around the world have been altered as a result of the social media revolution. It is anticipated that this will have an impact on the news consumption patterns of the general public, particularly with regard to the content of traditional mass media outlets. Indeed, social media platforms such as Twitter have had a significant impact on democracy and politics, social movements, international relations, businesses, and economies around the world in recent years.

\section{THEORETICAL FRAMEWORK MEDIA IMPERIALISM}

Omoera and Ibagere (2010), posit that in media imperialism, a scenario is described as one in which the media system of a certain region or country of emphasis is subjugated to the demands of the media system of another country. Boyd-Barrett (1977), provides a succinct definition of media imperialism, although one that is a little out of date. According to him, it is the procedure by which. The ownership, structure, distribution, and content of the media in any one country are individually or collectively subject to significant external pressure from the media interests of any other country or countries without a proportionate reciprocation of influence on the part of the country that is being pressured. It is evident from the concept expressed by Boyd-Barrett that the result of the pressure is acculturation. In this regard, it should be emphasised that the nation or countries who start imperialism do so either by accident or as a planned, purposeful strategy, or business strategy. On the other hand, the country involved also accepts the influence as a purposeful economic or political strategy after the invasion, without paying much attention to its effects. It is also true that the nation thus invaded may be weak and cannot withstand the invasion even if it wanted to. Several reasons are responsible for the incapacity to resist, including poverty in all its consequences, which may hinder an invaded nation from developing its own media system which is powerful enough to fight imperialism. Eregare and Afolabi (2009), correctly remark in this respect that media-imperialism is a critical theory of the perceived impact of globalisation on the media in the globe. They argue that media imperialism operates when a single business or corporation controls all media in a nation or country standardising and marketing the goods of a certain culture for media consumption. For example, the impact of American media material simply increases consumer values, not production values, in many nations that are forced by the prism of Western values, ideas and civilisation to rely upon and to see the world.
This is presumably what Boyd - Barrett (1977) dependence syndrome when he identified four modes of media imperialism. These are:

(i) The shape of the communication vehicle

(ii) A set of individual arrangement for the continuation of media production

(iii) The body of values about ideal practice

(iv) Specific media content.

While the new media might be the subject being examined for this study, the audacity of an a foreign based company to make arbitrary choices about who gets to say what, when, and how is clearly depicts elements of media imperialism.

\section{ANTECEDENTS THAT LED TO THE TWITTER BAN IN NIGERIA}

1. 2020 EndSars protest: Towards the tail end of 2020 when Nigerians were protesting against police brutality, one major platform that was effectively able to amplify the voice of Nigerians all across the nation was the twitter app. Experts however believed that Nigerian government was not particularly happy with the development.

2. The failed Social Media bill: President Buhari has been criticised way back from his first tenure in office for being obsessed with digital dictatorship using social media as a springboard. One of the clear indications of his intolerance to freedom of the Internet was in March 2019, when he rejected approval of the National Assembly's crucial digital rights law. Buhari didn't speak lightly of his internet censorship at the end of that year. "Our attention is increasingly being focused on cyber-crimes and the abuse of technology through hate speech and other divisive material being propagated on social media. Whilst we uphold the constitutional rights of our people to freedom of expression and association, where the purported exercise of these rights infringes on the rights of other citizens or threatens to undermine our National Security, we will take firm and decisive action," he said. One month following his comments, a government-backed bill aimed at regulating social media came to the National Assembly. Among those who endorsed Internet Falsehood and Manipulation Protection and Other Related Matters Project 2019 was Senator Elisha Abbo, a legislative author who was hit in social media after he was taped on a sex shop attack on a woman. 


\section{SJIF Impact Factor 2021: 8.013| ISI I.F.Value:1.241| Journal DOI: 10.36713/epra2016 \\ ISSN: 2455-7838(Online) \\ EPRA International Journal of Research and Development (IJRD)}

The law proposing a punishment of $\mathrm{N} 300,000(\$ 733)$ or three years in jail or both (for an individual) for defaulting persons suffered a major setback after it was overwhelmingly opposed at public hearings.

3. Renewed secessionist agitations across the country: In Nigeria, increasing insecurity and community violence seem to encourage separatist movements across the nation. Among these movements is the Biafra Indigenous People, a group in Nigeria that advocated an independent state more than 50 years ago. While it is true that back in 2017 , the government banned the activities of the secessionist movement group IPOB which were led by British Nigerian activist Nnamdi Kanu. The separatist organisation, nevertheless established an armed security force in January. The goal was to repel Fulani herdsmen, who are frequently accused of community conflicts in the area. But the unit is considered subversive by the Nigerian government. Troops in places where it is operating have clamped down on the armed organisation. Similarly, a separatist party of Yoruba has emerged in recent months advocating for the establishment of an independent state called the Oduduwa Republic. The Republic would encompass the south-west portions of the nation, including the economic centre of Nigeria, Lagos. According to Ibrahim (2021), many Nigerians are extremely unhappy with our political community. You believe that it is not organised to suit your interests. They believe that their citizenship is useless due to severe marginalisation. Apart from insecurity, the emergence of these separatist groups is to blame for political marginalisation.

\section{BAN OF TWITTER IN NIGERIA}

The federal of government Nigeria on the $4^{\text {th }}$ of June 2021 announced an indefinite suspension of Twitter in the country. This was two days after the company deleted a controversial tweet from the country's president. The social media platform removed the post by president Buhari saying it violated the site's rules against abusive behaviour. In the tweet, Buahri threatened to punish members of a secessionist movement in the country's south east.

"Many of those misbehaving today are too young to be aware of the destruction and loss of lives that occurred during the Nigerian
Civil War. Those of us in the fields for 30 months, who went through the war, will treat them in the language they understand".

The government cited "persistent use of the platform for activities that are capable of undermining Nigeria's corporate existence," as reason for the ban that took effect almost immediately. Following the ban however, the Nigerian government through the information minister questioned twitter's actions, labelling them as "very suspect". He accused twitter of double standards, saying the company had ignored what it considered to be violent messages from a separatist leader.

"When people were burning police stations and killing police men in Nigeria during the Endsars, for Twitter it was about the right to protest, but when a similar thing happened on the capital it became insurrection. Twitter may have its own rules, but it is not a universal rule, if Mr. President anywhere in the world feels very bad and concerned of a situation, he is free to express such views... we are not going to be fooled by anybody. We have a country to rule and we will do so to the best of our ability".

The ban came much to the displeasure of many Nigerians. This is due to the fact that Nigeria being the most populous African country is widely believed to be the largest market base for the social media platform with an estimated 39.6 million users. According to a statement from the US based outfit:

"We are deeply concerned by the blocking of Twitter in Nigeria. Access to the free and open internet is an essential human right in modern society".

In addition, the government ordered broadcasters to cease their "patronage" of the platform. It labelled the broadcast stations' continued use of the technology as "unpatriotic." Media and human rights activists decried the broadcast regulator's decision, calling it "illegal" and an assault on press freedom, but major broadcast stations remained off Twitter in order to comply with the order. Two months after the ban, the Nigerian government indicated that the temporary ban on Twitter could be removed soon, with information minister Lai Mohammed stating that negotiations with Twitter were still continuing and that many agreements had been made with the social media platform. Many Nigerians, civic organisations, and members of the foreign community have spoken out against the ban on Twitter.

With the ban, Nigeria joined the list of other countries that have banned or temporarily suspended Twitter, including China, Iran, North Korea, 


\title{
EPRA International Journal of Research and Development (IJRD)
}

\author{
Volume: 6 | Issue: 9 | September $2021 \quad$ - Peer Reviewed Journal
}

Egypt and Turkey. Despite the ban, many Nigerians still have access to the site using virtual private networks (VPN) and can share their opinion on other apps, like Indian-based microblogging site Koo. According to the US embassy in Nigeria, key diplomatic and economic partners including the EU and the US all criticised the restriction as it comes at a time when the nation needed to promote open discourse and express views and to communicate critical information about the COVID-19 epidemic. According to Golubski (2021), the worldwide focus of the ban also shows the obvious inefficiency of the administration in tackling major economic, social, security and political problems. Banning systems of expression is not the answer, these measures inhibit access to information and commerce.

From the bilateral point of view, the ban once again put Nigeria under the spotlight for the wrong reasons. According to Asandu (2021), despite the fact that Nigeria is Africa's largest economy, the country has often lost out on significant economic possibilities, mostly as a consequence of government policies that have undermined investor trust. The ban has also hampered Nigeria's development as international investors now push businesses and finance to other African nations, threatening Nigeria's position as Africa's unofficial innovation centre. Recently, in a case where Ghana has a considerably smaller population and economy than Nigeria but was considered to have an appealing environment for foreign investors, Twitter selected Ghana for its headquarters. Many startup company concepts also demand an active presence in social media which may make attracting investors challenging for Nigerian technology entrepreneurs. With a recent World Bank Ease of Doing Business study, the nation was rated 14th in Africa overall. However, the government's growing intolerance, along with the country's deteriorating economy, has the potential to reverse much of the progress that has been made over the years. Furthermore, according to a Premium Times (2021) report, opposition politicians and civil society organisations have also criticised the government over the ban, and several human rights organisations have filed a lawsuit against the Nigerian government at the ECOWAS Court against the government. According to an interim order, the government and its agents were prohibited from unlawfully imposing sanctions or doing anything else to harass, intimidate, arrest, or prosecute Twitter and/or any other social media service providers, media houses, radio and television broadcast stations, the plaintiffs, and other Nigerians who use
Twitter, pending the hearing and determination of the case by the ECOWAS court.

From the socio-economic point of view, Nigeria reportedly lost $\mathrm{N} 247.61 \mathrm{bn}$ within the first one hundred days of the ban. According to NetBlocks, a watchdog organization that monitors cyber-security and governance of the Internet, about $\$ 366.88 \mathrm{~m}$ has been lost by businesses since the shutdown took effect. The toll also showed it cost Nigeria's economy $\$ 250,600$ (N103.17m) every hour. According research conducted by statisca (2021), Nigeria has about 33 million social media users, with about $26 \%$ on twitter. Asandu (2021), posits that Nigeria is has one of the world's largest rates of severe poverty, with over half its people estimated to live on less than 1.90 dollars a day. It is also tackling its worst rate of unemployment and inflation, at $18.12 \%$, and is rated as Western Africa's second most corrupt country, according to the Transparency International Corruption Perception Index, the worst ranking since 2015. While this statistics are worrying enough, the twitter ban will only worsen things. According to Nwokoma (2021), small and medium-sized enterprises (SMEs) are critical to the development of any economy, often supplying as much as 60-70 percent of the country's employment opportunities. Small and medium-sized enterprises (SMEs) in Nigeria account for 96 percent of all companies and provide 84 percent of all employment. With a population of about 117.4 million, SMEs provide 48 percent of the country's GDP and account for 96 percent of all businesses. Many small and medium-sized enterprises (SMEs) have taken use of the Internet, particularly social media, to conduct commercial operations such as marketing and customer support. The large number of merchants on social media platforms such as Twitter and Instagram is evidence of this. This view is further corroborated by Anyim (2021), who affirmed that millions of small and medium-sized businesses who rely on the platform to contact their consumers have already seen a reduction in their ability to access the market as a result of the suspension. While these companies may choose to use other social media sites, their postings may not get the same level of interaction as those on Twitter. This has the potential to exacerbate the difficulties that companies have faced as a result of COVID-19 and other structural flaws. The e-commerce industry in the nation, which is estimated to be worth $\$ 12$ billion, is also impacted (Iyatse and Adepetun, 2021).

From the socio-political point of view, it is worthy to note that the social media particularly the twitter played a key role in mobilizing support during the electioneering campaign of President Buhari. 


\section{EPRA International Journal of Research and Development (IJRD)}

According to Usman, cited in Asandu (2021), the suspension will strain the federal government's connection with various stakeholders across the country including the youths, the press men, the legal practitioners, health workers and so on. This worsening in relations with state societies is not just after EndSars demonstrations last October, but also the pervasive insecurity which seems to encompass the nation. In addition, since December 2020 instability has caused several schools to shut down with at least 800 schoolchildren and university students kidnapped. The Boko Haram terror sections and armed organisations, colloquially known as bandits, are expanding throughout different areas of the nation, while the conflict has engulfed southeast states, coupled with the incessant herdsmen attacks in Benue and the religious crisis in Plateau state. The actions of the administration reinforce the impression that they are more concerned with the regime's survival than address severe problems of violence and insecurity in Nigeria, says Usman in a report from Africa. The Twitter ban was imposed quickly but the same speed was not apparent in the use of digital technologies to, say, trace abductors, arrest terrorists and face other criminally killed people across the nation.

Otobo et. al (2021), during their study on the Impact of ban of Twitter on the psychomedical and socioeconomic life of young health professionals and trainees in Nigeria argued that although twitter may be a simple application for social networking to others, it is much more for Nigerians. It is a voice, a comfort and a community with an environment for everyone. Healthcare professionals are not excluded. In addition, there are still many ambiguities and mysteries in the field as future trainees and young health professionals. This issue was resolved by older, more experienced and diversified colleagues who assist juniors in the profession with career and patient management advice. In addition, twitter offered an up-to-date, uncertified but verified Continued Medical Education (CME), an imperative of medical practice. As medicine is a big and constantly evolving profession. Field researchers frequently posted summaries and links to their work on the application for access by other peers.

\section{CONCLUSION AND RECOMMENDATION}

Based on the foregoing, it is quite evident that the ban by the Nigerian government on twitter in the country has not benefitted either the government, the citizens and the American based social media company in any way. From the political point of view it has created a strained relationship between the government and a cross section of its citizens, from the economy point of view, it has resulted in massive loss of funds especially for business owners, and from the international point of view it has not given Nigeria a good image especially in the international community. In order for the ban to be lifted, the Nigerian government wants the American based corporation to register twitter as a company in the country and also have representatives in the country. Negotiations have ever since been made between the two parties and the federal government agreed to lift the ban, much to the delight of many Nigerians. While president Buhari's administration has shown a lack of regard for the rule of law and freedom of expression, banning Twitter in its entirety is a barely disguised effort by the government to suppress the expression of dissent, and Nigerians have good cause to be concerned. However, the ability of a foreign based company to make arbitrary choices about who gets to say what, when, and how is somewhat considered an illogical pandemonium. Taking a unanimous action over an arbitrary set of rules to deny people the right to speak out and yet trying to be the champion of free speech will amount to talking from both sides of the mouth. It raises concerns about regulating speech and suppressing unpopular viewpoints, particularly in light of the necessity for open public discussion in a free democratic society, among other things. Adaobi (2021), submits that if the Nigerian government's decision to prohibit the use of Twitter was dictatorial, it was much more problematic for an American sitting in a chair in Silicon Valley to interject themselves into the internal affairs of a sovereign African state. The unintended fallout of the scenario is a tale of two wrongs which has resulted in a "lose-lose" situation.

\section{RECOMMENDATIONS}

1. One of the demands of the federal government in order for the ban on twitter to be lifted is the establishment and registration of the company as a business enterprise in Nigeria. The lifting of the ban should be followed by a quick implementation of this demand. Representatives of the corporation in Nigeria will have a much better understanding of Nigeria's socio-political landscape and this will enable them make informed reports to their bosses.

2. Foreign owned media organizations should address issues from a much wider perspective so as to avoid creating a much bigger problem while trying to solve one as in the case of what led to the twitter ban in Nigeria. 


\section{SJIF Impact Factor 2021: 8.013| ISI I.F.Value:1.241| Journal DOI: 10.36713/epra2016 ISSN: 2455-7838(Online)}

EPRA International Journal of Research and Development (IJRD)

Volume: 6 | Issue: 9 | September 2021

3. The Nigerian government through its actions and inactions appears to be indulging in all sorts of antics at gagging the media in Nigeria especially through the different anti-press laws and bills, there is therefore need for a change of attitude on the part of the government so as not to be seen as dictatorial. Freedom of the press is crucial in any democracy and should be encouraged in Nigeria.

4. The statistics of amounts lost as a result of the twitter ban in Nigeria shows the effect that social media does have on the socio-economic landscape in Nigeria. Efforts should therefore be made by various stakeholders towards reviving businesses and commercial activities on the platform especially in an era when the country is faced with a plethora of economic hardship.

\section{REFERENCES}

1. Akase et. al, (2020). Evaluation of Social Media Influence on the outbreak of Covid-19 in Nigeria. volume 5 , no. 1

Mkar journal of media and culture

2. Asadu, C. (2021, July 20). Nigeria's Twitter blackout: What's really behind Buhari's social media ban? The Africa Report.Com.https://www.theafricareport.com/9528 O/nigerias-twitter-blackout-whats-really-behindbuharis-social-media-ban/

3. Anyim, Wisdom Okereke, (2021). "Twitter Ban in Nigeria: Implications on Economy, Freedom of Speech and Information Sharing" (2021). Library Philosophy and Practice (e-journal). 5975. https://digitalcommons.unl.edu/libphilprac/5975

4. Boyd-Barrett, O., \& Thussu, D.K. (1993). NWIO strategies and media imperialism: The case of regional news exchange. In K. Nordenstreng \& $H$. Schiller (Eds.), Beyond national sovereignty: International communication in the 1990s (pp. 177-192). Norwood, NJ: Ablex Publishing Corporation.

5. BBC News. (2021, August 14). Viewpoint: Why Twitter got it wrong in Nigeria. 58175708 https://www.bbc.com/news/world-africa-

6. Edogor (2014). Influence of social media on youths' usage of traditional mass media in Nigeria.New media and mass communication www.iiste.org. ISSN 2224-3267 (paper) ISSN 222 3275 (online) vol. 31,2014

7. Eregare, E, A., \& Afolabi, A.O. (2009). The effects of globalization and deregulation on Nigerian culture industries. Journal of Social Sciences, 21(2), 145-151.

8. Free speech wars | Twitter angry over ban in Nigeria after erasing president's tweet. (2021, June

\section{- Peer Reviewed Journal}

7).[Video].

YouTube. https://www.youtube.com/watch? $v=C_{-} a 2 r Q D G I C 4$

9. Golubski, (2021, August 11). Nigeria's Twitter ban is a misplaced priority. Brookings. https://www.brookings.edu/blog/africa-infocus/2021/08/11/nigerias-twitter-ban-ismisplacedpriority/

10. Iyatse, G. and Adepetun, A. (2021, June 7). $\$ 12 b$ ecommerce suffers as Twitter ban costs N7.5 billion in three days. The Guardian, 37 (15, 502) pp. 1-2.

11. Maduabuchi, E. (2011). Nigeria: FOI Act, the morning after. http://allafrica.com. Retrieved March 10, 2012.

12. Malayo K.A (2012) An Evaluative Study of The Freedom Of Information Act And Media Practice In Nigeria. (Being a Research Project Submitted to the Department of Mass Communication,

Faculty of Arts, University of Nigeria, Nsukka in Partial Fulfillment of the Requirements for the Award of Masters of Arts Degree in Mass Communication)

13. Nwokoma, C. (2021). 4 Ways Nigeria's Twitter Ban Could Affect Businesses. Retrieved July 12,2021 from https://techpoint.africa/2021/06/05/nigeriatwitter-ban/

14. Obiezu, (2021, May 25). In Nigeria, Rising Insecurity Leads to Growing Separatist Calls. Voiceof America. https://www.voanews.com/africa/nigeria-risinginsecurity-leads-growing $\quad$-separatist-calls

15. Omoera and Ibagere (2010). Revisiting Media Imperialism: A Review of the Nigerian TelevisionExperience. The International Journal of Research and Review. Volume 5. ISSN 2094 1420

16. Omoera, O. (2011). The quest for more effective media and the freedom of information act inNigeria. Retrieved from https://www.researchgate.net/publication/52003693

17. Otobo et al., (2021). The Impact of Ban of Twitter on the Psychomedical and Socioeconomic Lifeof Young Health Professionals and Trainees in Nigeria. Biomed J Sci \& Tech Res 36(5)-2021. BJSTR. MS.ID.005902.

18. Rodman, G. (2020). In a changing world-History industry controversy (3rd ed.). New York

19. Talabi, F. O. (2011). The Internet and Journalism practice in Nigeria. Global Journal of HumanSocialScience, 11(10), 48. 